\title{
ENTREPRENEURSHIP AND INNOVATION AND SOCIAL ENTREPRENEURSHIP IN VIETNAM: AN EXAMINATION FROM INSTITUTIONAL AND IDEOGRAPHIC LENS
}

\author{
Quan Vu Le a $^{a^{*}}$, Yolanda Sarason ${ }^{\mathrm{b}}$ \\ ${ }^{a}$ Albers School of Business and Economics, Seattle University, Seattle, USA \\ ${ }^{b}$ The College of Business, Colorado State University, Colorado, USA \\ *Corresponding author: Email: lequ@ seattleu.edu \\ Article history \\ Received: March 20 ${ }^{\text {th }}, 2018 \mid$ Accepted: March 26 ${ }^{\text {th }}, 2018$
}

\begin{abstract}
This paper is an introduction to the special issue of Dalat University Journal of Science Economics and Management on entrepreneurship in Vietnam. There are four papers in this special issue. The first paper examines the impact of institutions on entrepreneurship using data from the Provincial Competitive Index. The second paper utilizes a different set of institutional indicators from the World Bank's Vietnam Enterprise Survey to assess the impacts of business environment on the development of SMEs. In both papers, the authors find that institutional factors such as entry barriers, lack of policy support systems, informal payment, provincial leadership, lack of access to finance, administrative and procedures, and tax inspections hindered the development of entrepreneurship in Vietnam. The third paper investigates the absence of medium-sized enterprises and the necessity for the development of such enterprises is critically important for Hochiminh City. Using primary and secondary data sources, the author presents a case study on two strategic sectors in the city. The result indicates that medium-sized enterprises are proven to be more effective than large-scale enterprises. The last paper focuses on social entrepreneurship in Vietnam. The authors use Hofstede's measure of cultural differences to compare social ventures in Vietnam and the United States.
\end{abstract}

Keywords: Entrepreneurship; Innovation; Social entrepreneurship; Vietnam.

Article identifier: http://tckh.dlu.edu.vn/index.php/tckhdhdl/article/view/448

Article type: Full-length review article

Copyright $\odot 2018$ The author(s).

Licensing: This article is licensed under a CC BY-NC-ND 4.0 


\section{INTRODUCTION}

The Government of Vietnam has recognized the private sector as one of the important factors to promote economic development. Entrepreneurship development and startup culture are gaining momentum in recent years from entrepreneurs in the business community, educators in academia, and policymakers at the local and national levels. In 2016, there were 110,000 new registered enterprises, the highest number in recent years. Currently, there are more than 500,000 small and medium-sized enterprises (SMEs), representing more than $97 \%$ of total registered enterprises in Vietnam. Along with the development of private enterprise, social entrepreneurship is also on the rise in Vietnam. The Vietnam Enterprise Law was revised in 2014 to provide a legal definition of social enterprise. If given proper recognition, social enterprises have the potential to impact sustainable economic development in Vietnam, especially in impoverished regions of the country.

Government involvement in entrepreneurship is critically important for the private sector to generate economic prosperity (Hwang \& Powell, 2006; Arc, Desai, \& Hessels, 2008; \& Arc, Audretsch, \& Strom, 2009). Government policy formulates the institutional environment in which entrepreneurial decisions are made. Some policies support entrepreneurship as a means for job creation; Others encourage research and innovation, and the development of financial institutions. This paper serves as an introduction to the special issue of the Dalat University Journal of Science - Economics and Management on institutions and entrepreneurial activity in Vietnam. There are four papers in this special issue. The objective is to examine the recent rise in entrepreneurial activity in the private sector including SMEs and social enterprises in Vietnam. In each paper, the authors offer recommendations for government involvement in the private sector to cultivate entrepreneurship and facilitate growth.

In the first paper, Tran and Truong (2018) examine the impact of institutions on entrepreneurship using data from the Provincial Competitive Index. In the second paper, D. Nguyen (2018) utilizes a different set of institutional indicators from the World Bank's Vietnam Enterprise Survey to assess the impacts of business environment on the 
development of SMEs. In both papers, the authors find that institutional factors such as entry barriers, lack of policy support systems, informal payment, provincial leadership, lack of access to finance, administrative and procedures, and tax inspections hindered the development of entrepreneurship in Vietnam. In the third paper, U. Nguyen (2018) investigates the absence of medium-sized enterprises and the necessity for the development of such enterprises is critically important for Hochiminh City. Using primary and secondary data sources, the author presents a case study on two strategic sectors in the city. The result indicates that medium-sized enterprises are proven to be more effective than large-scale enterprises. The last paper focuses on social entrepreneurship in Vietnam. Sarason, Yuthas, and Nguyen (2018) use Hofstede (1980)'s measure of cultural differences to compare social entrepreneurship in Vietnam and the United States. The authors conclude that understanding cultural differences with an ideographic lens is an essential step toward partnerships between ventures in Vietnam and the United States.

This introduction paper is organized as follows. Section 1 describes the objective of the special issue on entrepreneurship. Section 2 provides the main findings of the four papers and recommendations. Section 3 concludes.

\section{ENTREPRENEURSHIP \& INNOVATION AND SOCIAL ENTREPRE- NEURSHIP IN VIETNAM}

In this section, we provide the main findings of four papers and recommendations by the authors to promote entrepreneurial activity in Vietnam. The first two papers examine the institutional factors at the national level using secondary data from the Provincial Competitive Index and the World Bank's Vietnam Enterprise Survey. The third paper presents the findings from a survey conducted in Hochiminh City in the electronic and information technology and mechanics sectors with a necessity-driven view. The last paper presents case studies of three social enterprises, namely, Fargreen, Vietnam Handicraft Initiative, and Tòhe to compare cultural differences in Vietnam and the United States using Hofstede's cultural dimensions theory. 
In the paper presented by Tran and Truong (2018), the authors examine the impact of institutions on entrepreneurship in Vietnam from 2005 to 2015 using secondary data from the General Statistics Office, Statistical Yearbook of Provinces, and the Provincial Competitive Index (PCI). Tran and Truong (2018) present four hypotheses based on the institutional framework of Fogel, Hawk, Morck, and Yeung (2009) and indicators of entrepreneurship defined in Zhou (2011). The authors find that institutional factor called entry barriers has a positive and statistically significant impact on the number of nonstate enterprises in the economy. This institutional factor represents the necessary resources and procedures that firms must have for market entry including entry cost, access, and stability in land use. The result suggests that less entry barriers are important in promoting the development of entrepreneurship in the private sector in Vietnam. The result is consistent with Zhou (2011)'s study on entrepreneurship and property rights protection in China.

Entry barriers also have a positive and statistically significant impact on the number of non-farm individual establishments in the economy. Individual business establishments depend on the enforcement of property rights, and improvement of administrative procedures. Potential entrepreneurs would be encouraged to establish new businesses if the registration time and procedures are streamlined. With the establishments of new non-state enterprises and individual businesses, job creation in the private sector will provide employment opportunities for the economy. Thus, the improvement of institutional quality has an indirect effect on private sector employment generation in Vietnam.

A second institutional factor that the authors attempted to analyze is the policy support systems. This factor examines the policy dimensions of institutions such as transparency, time costs, business support services, labor training, and legal institutions. Tran and Truong (2018) find that policy support has a positive and statistically significant impact on employment in non-state enterprises. They argue that the policy impact on nonstate enterprises does not reflect the quantity of new private enterprises or individual business establishments, but it does on the job creation in the private sector. 
The third institutional factor deals with informal charges and provincial leadership. This factor describes corruption behavior of provincial officials, and the dynamism and creativity of provincial government in implementing central government policy. The result indicates that less corruption and strong provincial leadership lead to a positive and statistically significant impact on the employment in the private sector.

In summary, Tran and Truong (2018) conclude that the institutional factor that has a positive impact on all four indicators of entrepreneurship is entry barriers. Thus, minimizing the cost of market entry, and improving land access and land use are important institutional qualities to support entrepreneurial activities and the development of the private sector in Vietnam.

D. Nguyen (2018) utilizes a different set of institutional indicators from the World Bank's Vietnam Enterprise Survey to assess the impacts of business environment on the development of SMEs in Vietnam in the period 2009-2015. The author uses employment growth of SMEs as a vital indicator of growth in the private sector of the economy. D. Nguyen (2018) utilizes the definition of business environment from Jauch and William (1988) to capture the external and internal conditions of the economy which directly or indirectly impact business activities. These conditions include institutional quality, control of corruption and informal payment, tax administration, access to credit, and infrastructure that are commonly expressed in the literature (George \& Prabhu, 2000; Barlett et al., 2001; Kumar, Rajan, \& Zingales, 2001; Baurer, 2005; Beck, Demirguc, \& Maksimovic, 2005; Kauffmann, 2005; Fisman \& Svensson, 2007; Aterido, Hallwarddriemeier, \& Pages, 2009; \& Kato \& Sato, 2014). In the current context of the Vietnamese economy, the author utilizes the following indicators to describe the business environment of the country: Access to finance; Collateral; Informal payments; Time of administrative and procedures; Tax inspections; and Power outage.

The results of D. Nguyen (2018)'s study reveal that access to finance has a positive and statistically significant impact on employment growth of SME sector. This is consistent with finding in George and Prabhu (2000). SMEs are perceived as a highrisk business, thus access to formal financial institutions is difficult. In order to obtain 
loans from commercial banks, the author recommends SMEs to have a thorough business strategy with a long-term vision that can mitigate risks. Furthermore, there are supporting organizations such as the Small and Medium Enterprise Development Fund and the Credit Guarantee Fund that address the financial bottlenecks constraining the expansion of SMEs.

Informal payments - an indicator of corruption; Time of administrative and procedures - an indicator of institutional quality; and Tax inspections - an indicator of the bureaucracy, all have negative and statistically significant impacts on employment growth of SME sector. The author concludes that tax inspections are perceived as the single most severe obstacles hindering the development of private entrepreneurship in Vietnam. The author calls for the implementation of information technology in tax administrative reform to reduce tax compliance and administrative costs. The author also recommends reforms that emphasis on streamlining the number of sub-licenses and reducing the administrative procedures to stimulate investment and competition in the SME sector. Last but not least, informal payments hinder the development of the private sector in Vietnam. Therefore, to prevent corrupted officials from rent-seeking and harassing entrepreneurs, the author strongly advocates for simplifying and rationalizing the regulatory loopholes and increasing transparency.

U. Nguyen (2018) compares medium-sized enterprises (ME) to micro-and-small enterprises (MSE) as well as to large enterprises (LE). The author provides evidence that the growth in smaller enterprises is increasing but the growth in medium-sized enterprises is remaining relatively stable. U. Nguyen (2018) proposes that the lack of growth of medium-sized enterprises is an obstacle to economic development in Hochiminh City. In particular, there has been low growth in the mechanical sector and the electronic and information technology sector of the economy.

The author describes these two strategic sectors using three data sources to show their role in developing the competitiveness of the industry and offers policy recommendations to overcome the low level of medium-sized enterprises. U. Nguyen (2018)'s research methodology consisted first of collecting secondary data of productivity 
among MSE, ME and LE organizations. Subsequently, a survey of entrepreneurs was conducted followed by semi-structured interviews with 20 selected industries experts.

The secondary research revealed that medium-sized enterprises have a higher average income per employee, more equity, lower turnover and higher profit than microand-small enterprises. Her investigation also provided evidence that labor productivity of medium-sized enterprises is higher than both micro-and-small enterprises and large enterprises. The survey results indicated that medium-sized enterprises have the following advantages over micro-and-small enterprises. The medium-sized enterprises have greater access to capital, greater investment in technology, better management resources, better access to production sites, better access to information and are more likely to link to external resources. The semi-structured interviews with industry experts yielded similar results. They indicated that medium-sized enterprises have advantages because of their ability to scale and be adaptable. Moreover, medium-sized enterprises have better access management expertise. In addition, the industry experts indicated that medium-sized enterprises are able to link to large enterprises and can set up a centralized market.

U. Nguyen (2018) offers the following policy recommendations. First, the development of medium-sized enterprises should be prioritized. Second, there should be an analysis of the needs by enterprise sector. In particular, the electronic and information technology sector has special needs for appropriate management talent and the mechanical sector needs financial services in order to scale. Both sectors would benefit from linkages to global supply chains and market information. Third, government programs should focus on providing capital and training to medium-sized enterprises and help remove barriers to entry. Fourth, a positive ecosystem should be fostered, as it would facilitate the growth of medium-sized enterprises. Fifth, associations should promote linkages for all enterprise groups. Sixth, it needs to be recognized that different industry sectors would require different strategies to be incentivized to promote growth. In summary, medium-sized enterprises have a better opportunity than micro-and-small enterprises for sustained economic development in the long run. 
Sarason, Yuthas, and Nguyen (2018) explored social ventures in Vietnam and contrasted them with social ventures in the US. They make the argument that social entrepreneurial ventures have traditionally been viewed with a nomothetic lens which focuses on universal, generalizable aspects of social ventures. They propose that much of this research has been conducted using a Western lens. They suggest that an ideographic lens is more appropriate when understanding social ventures in Vietnam. An ideographic lens seeks a deep understanding of ventures to provide insights into real relations and structures.

After providing a brief history of social ventures in Vietnam, the authors describe Hofstede's measure of cultural differences (Hofstede, 1980). They draw upon the scores on Hofstede's dimension when comparing American culture to Vietnamese culture. This comparison suggests that Vietnam and the US. are meaningfully different on all of six dimensions of the cultural measure. Vietnam scores higher on power distance and longterm orientation. The US scores higher on individualism, indulgence, masculinity and uncertainty avoidance.

Sarason, Aziz, and Fifield (2017) draw upon three social venture cases in Vietnam to illustrate propositions regarding managing social enterprises from a Vietnamese cultural lens in contrast to managing social enterprises using an American lens. One case focuses a Vietnamese woman starting a for-profit social venture (Sarason et al., 2017), one focuses on an American working with a social venture (Easter \& Dato-on, 2015), and one represents a more well-known relatively successful Vietnamese social venture (Seno \& Nguyen, 2017).

The authors draw upon these cases to develop propositions about differences in the management of social ventures in Vietnam and social ventures in the US. They propose that social ventures in Vietnam will be more associated with the venture than the entrepreneur, will be more hierarchical, and will have a longer time horizon for impact. They propose that Americans will be more likely to focus on the entrepreneur, be more direct in communication style, more financially focused and will place a higher emphasis 
on measuring and communicating impact performance as well as expect clear control systems.

Sarason et al. (2017) provide implications for American and Vietnamese managers of social ventures that work together. Because Americans are more individualistic and Vietnamese are more collectivist, the relationships will be facilitated if Americans recognize that it is important to gain acceptance from the entire social venture team and that long-term relationships are to be expected and respected. Vietnamese managers should recognize that it is common for Americans to attribute successes to individuals rather than the organization as a whole. Since there is a greater power distance in Vietnamese social ventures, it will be more effective for Americans to work with individuals with designated authority. Moreover, Vietnamese managers should recognize that their American partners may expect direct, parallel communication and that informality is common as is questioning authority. Since Americans are more likely to be indulgent, both parties should recognize that it is common for Americans to be more self-interest driven and for Vietnamese to be more focused on the common good. Because of the differences in time orientation, both parties should focus on both short-term consequences as well as the long-term consequences of all partnerships. Because the Vietnamese culture is a more feminine culture, both parties need to recognize that selfpromotion is not common and accomplishments may be understated in Vietnam. Since Americans are less comfortable with uncertainty, both parties should recognize that formal control systems are not the norm in Vietnamese culture and accommodations from both sides would foster a more meaningful relationship.

The authors conclude that as we move toward a more global marketplace, partnerships between Vietnamese ventures and US. ventures will be more common. With social ventures, both partners want to achieve the social missions they are committed to achieve. Given the potential of social ventures to address social issues such as poverty, climate change, and pollution, it is imperative that both sides understand how to work together to have an even greater impact. Understanding cultural differences with an ideographic lens is an essential step toward these goals. 


\section{CONCLUSIONS}

This is an exciting time for the economic development of Vietnam. The increase in entrepreneurial activity has the potential to provide a higher standard of living across all sectors of the economy. It is early to see the full impact of the passage of the Vietnam Enterprise Law in 2014; However, it has a potential of addressing serious social and institutional problems. The authors in this special issue have provided concrete recommendations for increasing entrepreneurial activity in Vietnam. These include decreasing entry barriers for enterprises, incentivizing small and medium enterprises. For social ventures, recommendations are offered to address cultural differences among partners. We are hopeful that these papers will help provide a foundation for future research in facilitating entrepreneurial activity in Vietnam.

\section{REFERENCES}

Arc, Z. J., Desai, S., \& Hessels, J. (2008). Entrepreneurship, economic development and institutions. Small Business Economics, 31, 219-234.

Arc, Z., Audretsch, D., \& Strom, R. (2009). Entrepreneurship, growth, and public policy. Cambridge, UK: Cambridge University Press.

Aterido, R., Hallward-driemeier, M., \& Pages, C. (2009). Big constraints to small firms' growth? Business environment and employment growth across firms (Working Paper No. WPS5032). Retrieved from https://openknowledge.worldbank.org/ handle/10986/4787.

Baurer, L. I. (2005). Tax administrations and small and medium enterprises in developing countries. Washington D.C., USA: World Bank.

Beck, T., Demirguc, K. A., \& Maksimovic, V. (2005). Financial and legal constraints to growth: Does firm size matter? The Journal of Finance, LX(1), 137-177.

Easter, S., \& Dato-on, C. M. (2015). Bridging ties across contexts to scale social value: The case of a Vietnamese social enterprise. Journal of Social Entrepreneurship, 6(3), 320-351.

Fisman, R., \& Svensson, J. (2007). Are corruption and taxation really harmful to growth? Firm-level evidence. Journal of Development Economics, 83(1), 63-75.

Fogel, K., Hawk, A., Morck, R., \& Yeung, B. (2009). Institutional obstacles to entrepreneurship. Oxford, UK: Oxford University Press.

George, G., \& Prabhu, G. N. (2000). Developmental financial institutions as catalysts of entrepreneurship in emerging economies. Academy of Management Review, 25(3), 620-629. 
Hwang, H., \& Powell, W. W. (2006). Institutions and entrepreneurship. In Z. J. Acs, and D. B. Audretsch (Eds.), The Handbook of entrepreneurship research (pp. 201232). New York, USA: Springer International Publishing.

Hofstede, G. (1980). Culture's consequences: International differences in work-related values. California, USA: Sage Publications.

Jauch, R. L., \& William, F. G. (1988). Strategic management and business policy. New York, USA: McGraw-Hill, Inc.

Kato, A., \& Sato, T. (2014). Greasing the wheels? The effect of corruption in regulated manufacturing sectors of India (Discussion Paper No. DP2014-07). Retrieved from http://www.rieb.kobe-u.ac.jp/academic/ra/dp/English/DP2014-07.pdf

Kauffmann, C. (2005). Financing SMEs in Africa. Policy Insights, (7), 1-4.

Kumar, K. B., Rajan, R. G., \& Zingales, L. (2001). What determines firm size? (Working Paper No. 7208). Retrieved from http://www.nber.org/papers/w7208.pdf

Nguyen, Q. D. (2018). Assessment of the impacts of business environment on the development of Vietnamese SMEs: Evidence from the enterprise survey. Dalat University Journal of Science - Economics and Management, 8(1), 40-59.

Nguyen, T. T. U. (2018). Necessity for the development of medium-sized enterprises in Hochiminh City: A case study of the electronic \& information technology and mechanical sectors. Dalat University Journal of Science - Economics and Management, 8(1), 60-82.

Tran, T. T., \& Truong, N. H. (2018). The impact of institutions on entrepreneurship: A case of Vietnam. Dalat University Journal of Science - Economics and Management, 8(1), 22-39.

Sarason, Y., Yuthas, K., \& Nguyen, L. (2018). Social entrepreneurial ventures in Vietnam: An ideographic lens. Dalat University Journal of Science - Economics and Management, 8(1), 83-112.

Sarason, Y., Aziz, A., \& Fifield, E. (2017). East meets West: Growing a for-profit venture in Vietnam. Retrieved from https://wdi-publishing.com/product/east-meets-westgrowing-profit-social-venture-vietnam/

Seno, A. S., \& Nguyen, L. (2017). Stories of women-owned enterprises: Tòhe Vietnam. Sydney, Australia: The University of Sydney.

Zhou, W. (2011). Regional deregulation and entrepreneurial growth in China's transition economy. Entrepreneurship and Regional Development, 23(9-10), 853-876. 